\title{
Sexualidade em instituições fechadas
}

Rose Moura*

Em 1986 a Comissão Nacional de Sexologia da Febrasgo reuniu alguns dos melhores trabalhos apresentados nos II a III Encontros Nacionais de Sexologia, realizados respectivamente no Rio de Janeiro, em 1984 e Belo Horizonte, em 1985, na publicação intitulada Sexologia-II, compilados por seu então vice-presidente Dr. Nelson Vitiello. Dentre aqueles trabalhos, podemos encontrar um que atraiu a nossa especial atenção em virtude de termos encontrado um conceito do significado de "Instituições Fechadas", realizado por Isméri Conceição que afirma: "Uma instituição fechada se constitui de um grupo dirigente que é responsável pela manutenção de 'fechada' e um grupo de internos que se submetem à situação de 'fechado'. O grupo dirigente atribui aos internos características específicas que diferem daquelas aceitas para os outros grupos da sociedade. Dentre as características, está a ausência de sexualidade dos internos".

* Psicóloga clínica. Diretora científica da Clínica integrada de Psicologia e sociologia (CLIPS - Brasília - DF. 
A partir deste conceito, procuramos saber o que ocorria dentro de uma das instituições religiosas - se é que assim podemos chamar - como a Igreja Católica, cujas doutrinas de alguma maneira estão inseridas no aspecto cultural de nossa sociedade.

É importante ressaltar que os dirigentes dessas instituições não consideram apropriado o termo de "fechado" considerando-se três motivos principais:

$1^{\circ}$ - Afirmam que "O ser humano é sexuado dos pés à cabeça, do nascer ao fim da vida" e assim são todas as pessoas, mesmo os presbíteros;

$2^{\circ}$ - Que "o celibato é um modo peculiar de realizar a sexualidade e, por este motivo, é extremamente perigoso instalar na formação uma oposição entre celibato e sexualidade";

$3^{\circ}$ - Que durante e após o processo de formação dos presbíteros, eles possuem a opção de sair do seminário ou da sua atividade pastoral quando assim o desejar, mesmo que por motivos ligados à sexualidade.

Neste caso, o termo mais apropriado seria o de "instituição separada", uma vez que a lei do celibato impõe aos seminaristas e aos presbíteros uma situação de minoridade social.

Seria uma tarefa bastante difícil, em virtude da realização deste Congresso, fazermos uma pesquisa que englobasse todas as Igrejas Católicas do nosso País. Em função disto, resolvemos buscar junto à Conferência Nacional dos Bispos do Brasil - CNBB, situada em Brasília, alguns dados que justifícassem essa maneira diferente de se vivenciar a sexualidade dos seminaristas, futuros presbíteros do Brasil.

Contamos com a notável ajuda do Pe. Manoel Godoy que forneceu-nos inúmeras informações de como a Igreja vivência a Sexualidade Humana. Em pesquisa a ser publicada, realizada pelo Pe. Manoel Godoy, sobre a "Situação dos Seminaristas Maiores no Brasil Resultados Estatísticos" - que teve a parte técnica feita pelo Centro de Estatística Religiosa e Investigações Sociais - CERIS - uma pergunta chamou a nossa especial atenção: "O que leva um candidato a deixar o seminário?". Devemos ressaltar que o questionário fora respondido por 3580 seminaristas, tendo o sigilo pessoal garantido; tal cifra corresponde a $63 \%$ dos seminaristas do Brasil; a média de idade é de 26 anos; e o tipo de pergunta fora estimulada, que obteve como resposta as seguintes situações: $30,3 \%$ responderam discemimento da vocação**, $20,8 \%$ responderam o processo de formação não ajudou a solidificar a sua opinião, $14,4 \%$ sem

* Entende-se por disermimento o "processo de reflexão em que se procum conbecer a vontade de Deus a respeito de um ponto determinado sobre o qual não se tem clareza suficiente. Trata-se de uma atividade espiritual, que deve ser realizada em clima de oração. 
informação, $10,8 \%$ falta de espiritualidade, $7,88 \%$ dificuldade na vida comunitária, 7,88\% outro caso, e somente $6,38 \%$ opção pelo celibato.

Em documento anterior sobre a "Situação e Vida dos Seminaristas Maiores no Brasil" publicado como "estudos da CNBB", em 1984, é ressaltada a influência marcante da figura materna no projeto vocacional. Tal documento denota uma espécie de incapacidade dos seminaristas de se desprenderem desse laço demasiadamente forte, que se expressa na renúncia a buscar uma realização autônoma de sua sexualidade. "Estariam de tal forma presos às compensações áridas dessa identificação primordial com a mãe, que não têm mais nem capacidade, nem interesse de assumir os riscos de tinha identidade masculina. Esses, em outras palavras, seriam homossexuais, latentes ou não, que teriam encontrado na vocação uma, justificativa cômoda e socialmente prestigiada para poderem fugir ao confronto pessoal com outro sexo'.

No $7^{\circ}$ Curso de Formadores de Seminários Maiores, realizado em Itapecerica da Serra - SP, entre os días 23 de janeiro de 02 de fevereiro de 1989, abordou-se o tema: Afetividade e Sexualidade no processo de formação presbiterial. Vale a pena ressaltarmos três princípios abordados: antropolóbicos a luz da revelação, do contexto da realidade social e das condições subjetivas do indivíduo.

Com relação aos princípios antropológicos à luz da revelação, afirmou-se que "aprouve a Deus criar o ser humano sexuado a de maneira diferenciada: homem e mulher. A sexualidade é uma realidade que pervade todo o ser humano, manifestando-se em todos os seus aspectos, desde o biológico e instintivo até o psicológico e espiritual”.

Quanto aos princípios do contexto da realidade social, foi dito que "num ambiente sócio-econômico como o nosso, marcado pela dominação dos mais fortes sobre os mais fracos a pela hegemonia dos valores comerciais, a afetividade e a sexualidade são compreendidas como necessidades susceptíveis de manipulação, exploração e consumismo. A sociedade nunca será transformada enquanto os grupos dominantes continuarem manipulando a população, principalmente a juventude, amarrando-a à satisfação do desejo sexual, sem ânimo para aspirações mais altas".

Por fim, os princípios das condições subjetivas do indivíduo levem consideração a contribuição das ciências psicológicas para a compreensão subjetiva do indivíduo, ressaltando as marcas que provém desde a fase intrauterine e que continuam a influenciar o seu comportamento nas diversas fases do desenvolvimento psicossexual. Quanto a isto afirmou-se que "na educação afetivo-sexual de uma pessoa não podemos prescindir do peso das experiências dos primeiros anon, nas etapas da evolução da personalidade, na estrutura do psiquismo em inconsciente e consciente, do processo de maturação, dos bloqueios e fixações e dos mecanismos de defesa para camuflar a própria fragilidade". 
Ainda nesse Curso, foram levantadas algumas manifestações de não-integração da sexualidade, dentre elas destacou-se o homossexualismo e a masturbação.

A atitude homossexual foi caracterizada como sendo a de indivíduos que buscam no parceiro do próprio sexo a sua realização afetiva (hornotrópico) ou genital (homossexual) e subdividiu-se em homossexuais periféricos àqueles indivíduos que possuem apenas tendências ou atos homossexuais ocasionais e homossexuais estruturados àqueles que possuem atitudes e práticas homossexuais já assumidas em sua estrutura humano-afetiva.

Quanto à masturbação, acreditam que seja um sinal de não-integração da sexualidade, uma vez que ao invés de levar a pessoa à comunhão de vida com o outro, a conduz à busca do prazer egoísta, ao fechamento sobre si mesmo, e um comportamento narcisista-. Afirmam ainda que "a masturbação não é causa da desintegração, mas sintoma de que algo não está bem na estrutura. da pessoa".

Já no $8^{\circ}$ Curso de Formadores de Seminários Maiores do Brasil, realizado em Fortaleza-CE, entre 17 e 27 de julho do mesmo ano, que contou com a participação de mais de 40 formadores de Seminários Maiores do Brasil, trataram do homossexualismo como sendo um fato presente e aceito em quase todas as culturas, fazendo exceção o mundo judeu-cristão, geralmente estando ligado à esfera religiosa. Afirmaram que "não se deve partir do pressuposto de que todo homossexual é 'anormal'. Vale porém, lembrar que a antropologia bíblica pressupõe o heterossexualismo".

Quanto as causas da masturbação, admitiram ser muitas, tais quais curiosidade, dificuldades de bom relacionamento com os outros, dificuldades na passagem de, sendo criança, chegar à vida de adulto, um complexo de inferioridade, uma resposta a críticas, etc.

Algumas atitudes pedagógicas foram sugeridas para que os formadores pudessem lidar com a questão da masturbação, dentre elas ressaltamos o acolhimento do fato com compreensão; a não dramatização nem a relativização da masturbação e, a ajuda na percepção das causas da masturbação, avaliando os aspectos da constância e intensidade.

Com relação ao homossexualismo, o $9^{\circ}$ Curso de Formadores de Seminários Maiores do Brasil, realizado em Campo Grande - MS, em 1990, sugeriu pistas para uma ação pedagógica em relação aos vocacionáveis, com tendência ao homossexualismo:

"1. Há dual premissas fundamentais: a) atitude pessoal de acolhimento e respeito à pessoa do homossexual; b) atitude de aceitação serene do seu dinamismo de amadurecimento sexual (autoconhecimento).

2. Estabelecer entre educador e educando uma relação de confiança: escutar, pacientemente, sem dramatizar o problema. 
3. Aprofundar o conhecimento de sua história, também sexual, levando o educando a dar-se conta de sua própria situação, partindo talvez, de aspectos mais facilmente observáveis (isolamento. ciúmes, autoritarismo, etc.) para chegar à discussão franca a direta de outros aspectos do comportamento.

4. Antes de mais nada é preciso cuidar para que a equipe de formadores se prepare devidamente para discernir com o candidato sua opção vocacional.

5. Distinguir certos traços evolutivos de comportamentos mais aprofundados e estruturados, sobretudo nos de mais idade. Em canon mais sérios, recorrer à ajuda de especialistas.

6. Haja uma pastoral vocacional séria que faça a seleção dos vocacionáveis, evitando, assim, o ingresso do homossexual".

Essas a outran medidas pedagógicas parecem não ter evitado certos acontecimentos indesejáveis para a Igreja.

No dia 11 de março de 1993, o jornal "O Globo" publicou matéria intitulada "Padre brasileiro condenado a 13 anos em Portugal ". Tratava do padre Frederico Marques Cunha, considerado culpado pela morte do escoteiro Luís Miguel, de 15 anos, e pela prática de homossexualismo com menores. Após o cumprimento da pena, o padre deverá pagar uma indenização de US\$ 33 mil aos pais do jovem.

No dia 22 de março o mesmo ano, o jornal O Estado de São Paulo publicou: "A Aids chega à Igreja". "Na Grande São Paulo, 15 padres já morreram; no Rio, só um médico tratou de 5: a Igreja vive a contradição de estar na linha de frente na luta contra a discriminação e no socorro às vítimas e, ao mesmo tempo, esconder seus doentes". $O$ artigo traz à tona $\mathrm{o}$ caso que abalou a comunidade religiosa paulistana do padre Benedito de Jesus Batista Laurindo, conhecido como padre Batista. Além disso, cita o caso da menina Sheila, de 5 anos, que teve sua matrícula recusada em uma escola particular e fora aceita pelo Colégio São Luís, uma das escolas católicas mais tradicionais de São Paulo. Em artigo intitulado "Acordo põe fim a disputa sobre herança de vigário ", o Estadão referiu-se ao caso do padre Antônio Firmino de Paiva, morto em 1987, também vítima de infecção pelo HIV. A Igreja sustentou a versão de que o padre havia contraído o virus numa transfusão de sangue, no Paraguai, até que um ex-seminarista, Moyses Machado Filho, em meados de 1988, tivesse declarado ter sido parceiro sexual do padre durante 5 anos. Hoje, o ex-seminarista trava uma batalha judicial, no fórum Central de São Paulo, com o pai do padre Paiva, pois antes de morrer, deixou um testamento destinando $50 \%$ dos seus bens para o pai e os outras 50\% a serem divididos entre Moyses e um outro rapaz da qual o padre tinha a guarda judicial.

No dia 03 de abril de 1993, o Correio Braziliense, um dos jornais de maior circulação de Brasilia, publicou o artigo "Quebra do celibato ainda incomoda Igreja - Apesar das rígidas restrições superiores, cerca de três mil padres trocaram a batina por esposas". A reportagem contou com 
depoimentos de padres casados ligados à RUMOS -Associação de padres casados, que teve como fundadores os padres Felisberto de Almeida e João Basílio Schmitt.

No dia 07 de abril de 1993, a Folha de São Paulo publicou: "Bispo vive escândalo sexual”. $O$ artigo trata da aceitação da renúncia, pelo Papa João Paulo II, de Robert Sanchez, de 59 anos, arcebispo da Santa Sé, no Novo México, sul dos Estados Unidos, por ter mantido relações sexuais corri $5 \mathrm{mu}-$ lheres. $\mathrm{O}$-assunto também foi tratado no Correio Braziliense, no mesmo dia, com o artigo intitulado: "Papa demite o arcebispo que praticava sexo".

Em 23 de outubro de 1993, o jornal Estado de São Paulo publicou entrevista realizada com o bispo D. Angélico intitulada: “D. Angélico nega que Igreja esconda doentes". Bispo admite que há religiosos contaminados e elogia apoio dado pela instituição aos infectados.

Em 27 de outubro de 1993, a revista ,VEJA publicou matéria intitulada "Dont Héber é gay". "Acusado de manter um caso homossexual com seu tesoureiro, abade de Olinda renuncia e foge do país ". A matéria também fez referência ao padre e pesquisador americano, Andrew Greeley, que afirma: "entre 2.000 e 4.000 sacerdotes americanos molestaram cerca de 100.000 menores de idade nos últimos vinte anos" e a uma outra pesquisa, publicada na revista Newsweek, que revelou: metade dos 57.000 padres que trabalham nas 188 dioceses em todo o país tem vida sexual ativa e, entre esses, 11.000 são homossexuais. Cerca de 500 padres, foram acusados até agora de abuso sexual na Justiça americana. Estima-se que a Igreja gaste cerca de 50 milhões de dólares por ano com o trtamento psicológico desses padres e com pagamento de indenizações às suas vítimas.

Em 09 de março de 1995, o jornal O Globo publicou: "Bispo anglicano admite que é homossexual". A matéria refere-se ao caso do Bispo anglicano aposentado Derek Raweliffe, de 74 anos, que revelou, em entrevista à televisão BBC de Londres, que descobriu sua orientação sexual aos 50 anos.

No dia 16 de abril de 1995, a Folha de S. Paulo publicou matéria referente ao posicionamento do Arcebispo de São Paulo, D. Paulo Evauristo Arns, referente ao uso da camisinha como sendo um "mau menor".

Já em 24 de abril do corrente ano, o mesmo jornal publicou uma matéria referente à campanha do padre de Pirenópolis contra a venda de camisinhas - e outras métodos contraceptivos. O assunto também foi veiculado pelo jornal Correio Braziliense, de Brasília, em 09 de abril.

Estes e muitos outros casos, trazem à tona uma necessidade de mudança de atitude por parte das autoridades eclesiásticas no que diz respeito a maneira na qual a sexualidade humana tem sido vivenciada por seus integrantes.

Resumindo, é apropriado afirmar que a Igreja tem enfrentado questões muito semelhantes às encontradas em outras instituições fechadas, tais como abuso, desvios e orientações sexuais, por maiores que sejam seus esforços no sentido de denominar-se instituição separada. É só o que tenho a dizer. 